\title{
IMPACT OF FAILURES: A REVIEW IN THE PERSPECTIVE OF SRI LANKAN CORPORATES
}

\author{
A.S.A. Samaraweera ${ }^{a}$, P.M.C. Thilakerathne ${ }^{b}$, C. Pathirawasam \\ ${ }^{a}$ Faculty of Commerce \& Management Studies, University of Kelaniya, Sri Lanka; \\ ${ }^{b}$ Faculty of Commerce \& Management Studies, University of Kelaniya, Sri Lanka \\ ${ }^{\mathrm{c}}$ Faculty of Commerce \& Management Studies, University of Kelaniya, Sri Lanka
}

DOI: http://dx.doi.org/10.38193/IJRCMS.2021.3401

\begin{abstract}
The primary objective of this study is to review corporate failures in a Sri Lankan perspective. Development history of failure prediction models are introduced followed by case extracts from published authentic sources from the world and Sri Lanka. Methodological approach follows the deductive approach. Factors leading to failure of Sri Lankan corporates are discussed with implications to economy, society and stakeholders. The review concludes by providing suggestions for future research in the domain of corporate failure model building in Sri Lanka to provide early warning signs to stakeholders.
\end{abstract}

KEYWORDS: corporate failure, implications to stakeholder, published articles, Sri Lanka

\section{INTRODUCTION}

Corporate failures have been a keenly researched topic throughout the history. Early visibility of potential companies which could fail is a valuable piece of information for making correct business decisions. Company failure could lead to impacting many stakeholders. These include customers/clients, suppliers, economic agents, financial institutions, auditors, consultants and policy makers etc. "Failure is defined as the inability of a firm to pay its financial obligations as they mature. Operationally, a firm is said to have failed when any of the following events have occurred: bankruptcy, bond default, an overdrawn bank account, or nonpayment of a preferred stock dividend" $[1]$.

Time series evaluation of financial results provides early warning signs of a potential financial distress phenomena. Financial distress causes value erosion of a firm which impacts many stakeholders [2,3]. The 'spiral-effects' of failure would impact the whole economy of a country [4,5]. Corporate failure may have direct impact on employment and economic welfare [6]. The social impact of corporate failure is larger compared to the impact of an individual firm [7]. The economic effects caused by financial scandals and corporate failures such as Enron, WorldCom, Kmart, Global Crossing, Parmalat, Lehman Brothers and others worldwide have renewed interest in the area of bankruptcy 
prediction $[8,9]$.

Though there has been a dearth of research in the area of predicting financial distress and corporate failure, but the phenomenon of failure still remains at large within the corporate environment. The primary objective of this paper is to analyse the factors leading to corporate failure in Sri Lankan companies through published sources.

Having provided and introduction to the corporate failure domain, the paper is structured as follows. The literature review section provides a brief summary from an empirical perspective in the domain of model building to predict corporate failure. The design section illustrates the methodology used by the researcher in extracting published articles. The next section demonstrates example of failure of global corporates followed by examples of Sri Lankan corporates. Causes leading to corporate failure is discussed in section six alone with mitigation measures. Section seven concludes and paper providing suggestions for future research in the domain of model building to predict corporate failure.

\section{LITERATURE REVIEW}

Failure prediction has been a keenly researched topic for the last 90 years. The early research was dominated by statistical techniques, namely; Univariate Analysis [1], Multivariate and Discriminant Analysis [2]. Post 1980, there was a switched to more flexible assumptions compared to the models built using Multivariate and Discriminant Analysis. Logistical regression which used Conditional Probability were incorporated in the model building exercise Ohlson [11] and Lennox [12].

A shift toward intelligent techniques was witnessed in model building post 1990. There were many models built using Artificial neural networks, Fuzzy inference systems, Genetic algorithms (GAs), their hybridizations (neuro-fuzzy, neuro-genetic, fuzzy-genetic), computationally intelligent methodologies such as support vector machines, boosted decision trees and random forests. Classification technique used by Bell et al. [13] and Khanna [14], Case based reasoning (CBR) of Kolodner [15], K-nearest neighbour (KNN) of Tam and Kiang [16], rough set model of Slowinski and Zopounidis [17] are some examples of prediction models built using Artificial Neural Networks.

With the evolution of research in distress prediction many categories of variables have been introduced to the model building exercise. Cashflow based variables, stock market based variables, corporate governance based variables, macroeconomic based variables etc. were introduced to enhance the prediction accuracy of models. Industry specific and country specific models could be found in literature which shows the importance in the early identification of distress firms.

This section provided a summary of the empirical research carried out in prediction of corporate failure. Having analysed the literature, the next section will introduce the design of the paper. 


\section{DESIGN METHODOLOGY}

The researcher intends to extract published articles from newspapers, magazines, web sites and other publishing sources in domain of corporate failure. Firstly, the researcher analyses the failure of global corporates followed by corporates in Sri Lanka. Source articles encompasses the period from 2000 to date.

Having introduced the design methodology of the paper, the next section will analyses the impact of corporate failure through published reports.

\section{Failure of Global Corporates}

There have been many corporate failures that have occurred around the world. Failure of Lehman Brothers on 18th September 2008 was one of the largest bankruptcy events in the history. Twenty six thousand employees lost their jobs, Federal Reserve Bank of US lent USD 85 billion to American International Group, a global insurance company, to cover credit default swap contracts, increase in borrowing rates and spike in defaults of home loans, significant erosion in pension funds and crash in stock market were witnessed in US due to the bankruptcy of Lehman Brothers. Apart from the impact in the US, collapse of Lehman Brothers had significant global impact. As a major issuer of commercial papers as a short-term debt instrument to the banking sector, collapse led to credit freeze across the world. Trade to the US was significantly impacted due to the lesser consumer spending in the US sending spiral impacts to the manufacturing and job market across Asia and Europe. Global stock markets witnessed one of the worst downturns after the Great Depression in 1930s. Countries such as Ireland, Spain and Greece etc. witnessed major debt crisis [18].

Enron Corporation failure on 2nd December 2001, was the largest bankruptcy in the world prior to Lehman Brothers collapse. The stocks of the company fell from a high of USD 90 in August 2000 to less than a dollar by end November 2001 eroding value amounting to a value erosion of USD 11 billion impacting investors and thousands of employees on their retirement savings in 401(K) accounts. The effect of failure of Enron included loss of trust in investors, increased in cost of capital, the slowness of deregulation, more demanding and comprehensive accounting procedures etc. The above constraints effected the total growth of the industry. Enron Corporations main lender J.P. Morgan Chase lost USD 500 million while other banks such as U.K.'s Abbey National USD 165 million, Barclay's, France's Credit Lyonnais and Royal Bank of Scotland lost USD 100 million respectively. Apart from the above banks which had directly lent to Enron, the loss on investors of "Surety bonds" issued by Enron was over several billion dollars [19]. With the collapse of Enron, new legislation in the form of Sarbanes-Oxley Act also known as SOX was introduced to protect the investors from fraudulent financial practices. Furthermore, the act prohibited company auditors performing any concurrent consultancy business for the same company. 
Apart from the above, bankruptcy filing of Kmart, WorldCom, Global Crossing, Parmalat etc. has impacted many stakeholders. There have been 7,128 fillings of Chapter 11 in 2020 which is an increase of $29 \%$ compared to the previous year as per the data by Epiq for the American Bankruptcy Institute [20]. Having reviewed the impact on global corporates, the next section will review failure examples with relevant to Sri Lanka.

\section{Failure of Sri Lankan Corporates}

Similar to the global failures mentioned in section 4, there have been many failures of Sri Lankan corporates. Some prominent corporate failures include Galadari Hotels (Lanka) Ltd., ETI Finance Ltd., Vanik Incorporation Ltd., Ceylinco Group, Golden Key Credit Company and the Finance Company Plc.

Golden Key Credit Card company failed and was closed on 18th of December 2008 marking one of the darkest days in the financial history of Sri Lanka. A deposit base of Rs. 26.5 billion made out of 9,054 depositors, made it one of the largest asset based financial companies in Sri Lanka [21]. Luring customers with attractive interest rates ranging from $16 \%$ to $35 \%$ was a salient point of the company to build up their deposit base.

The social impact was immense due to the failure of Golden Key Credit Card company. During the initial few months, the failure of the company led to death and suicide of ten people. The failure of Golden Key Credit Company led to failure of many of the other companies of the Ceylinco Group impacting many stakeholders related to the group. Among the many stakeholders impacted, the Western Province had a Rs. 3 billion cashflow impact. The Central bank of Sri Lanka had to intervene to safeguard the depositor with cabinet granting approval of upto a payment of $41 \%$ of the deposit value [22]. Furthermore, Government of Sri Lanka and the Central Bank of Sri Lanka (CBSL) intervened by appointing a new board of directors, new management team to save Seylan bank from a potential sale which would have had a ripple impact on the economy and stakeholders of the bank.

Pramuka savings and development bank limited, incorporated in 1997, was the first bank to be liquidated after obtaining independence in Sri Lanka effecting many stakeholders including regulators, banking and financial sector, economy, government, depositors and general public. CBSL granting a license only to operate a savings and development bank, not possessing the "parate execution rights" which require to sell mortgage property when the loans have been defaulted by customers, CBSL not approving opening of branches to expand the operation and mismanagement are cited as the main reasons for failure of the bank in 2002 [23]. Furthermore, violating laws and regulations such as crediting the retirement contribution of Employees' Provident Fund of employees to an unapproved fund and investing back in the bank was a serious violation of labour laws in the country. Window 
dressing practices by transforming an operational loss of Rs.16.5 million to a profit of Rs. 8.3 million in 1999, managing director approving loans above his limits, lack of policy documentation in investment and done at the sole discretion of the managing director, performing business activities other than the branch office without prior approval, investing 13.9\% of the Bank's capital funds in Pan Asia Bank above the approved $10 \%$ by the CBSL on single unquoted company are some examples of regulatory and lawful violations done by Pramuka savings and development bank. More than 15,000 depositors were impacted amounting to Rs. 3.2 billion due to the winding up of Pramuka bank. Unable to bear the loss of their life long savings three people have committed suicide, one person died of a heart attack and 14 others had suffered strokes upon hearing the news of the bank closure proving a significant social impact. The weaknesses in bank supervision system, the high interest rates for deposits and lending, weaknesses in the macroeconomic policies and business failures were highlighted as causes of the failure [23]. The failure of Pramuka bank led several other failures such as Mercantile Credit Limited, Union Trust and Investment Ltd, House and Property Traders Ltd, Translanka Investments Ltd and Home Finance Ltd, Seylan bank crisis and also pyramid scheme system followed by the Sakvithi group fraudulent activity [24].

Edirisinghe Trust Investment Finance Limited also known as ETI Finance Ltd. and Swarnamahal Financial Services PLC. are two recent failures with a combined asset base of Rs. 38.5 billion. Though the first warning were issued by Fitch rating in 2013, the Monetary Board of CBSL issued restrictions in operation only in 2018 while eventually cancelling the license on 13th July, 2020 [26] impacting around 24,000 individual depositors. The impacted depositors were paid Rs. 600,000 through Peoples bank on the instructions of the Central Bank of Sri Lanka. The Sri Lanka Depositors Insurance Scheme was used to pay off the above funds [25].

The license of Sri Lanka's oldest finance companies, The Finance Company PLC, was cancelled on May 22, 2020 by the Central Bank of Sri Lanka. With more than 46 branches and 12 service centres across the country, company was renowned for customer convenience in a product portfolio of fixed deposits, savings, personal loans, leasing, hire purchasing, pawning, property development, and real estates to Sri Lanka. The cancellation of license effected 145,172 depositors [27]. The CBSL had to intervene by providing relief through the Sri Lanka Deposit Insurance and Liquidity Support Scheme to the $93 \%$ of the depositors amounting to Rs. 4.7 billion while the rest had an amount of Rs. 22.5 billion which was to be paid of through the liquidation proceeds as per the priority of claims. As shown above, only $17 \%$ of value was covered by the insurance scheme while the rest $83 \%$ of the payments remains unpaid [28]. Furthermore, evaluating the demographics of the depositors, many were retired personals, depositors with expectations for the future such as for their medications, surgical operations, children's education and to purchase properties commence a business and other important reason [29]. Therefore, the impact on the society was immense due to the failure of the company. The order of the Government of Sri Lanka to stop the normal course of business of 'The Finance Company' 
has diminished depositors' confidence and caused premature withdrawal deposits of other financial institutions [27]. Consequently, this situation passed negative signals to the entire final market and eventually resulted to reduce savings mobilization of the country.

Sri Lanka been an economy of USD 84 billion, a slight change in macroeconomic factors would effect the business environment. Furthermore, as many businesses interdependent and operate as cartels, a failure of one corporate have a ripple effect on the others. As per the International Monetary Fund (IMF) report [30], 15 licensed finance companies out of 46 in the country, which is $33 \%$ of the total licenses finance companies, are facing liquidity issues. Furthermore, this review elaborates that among the 15 companies 6 are at a high level of distress with non performing loans ranging from 50 to 90 percent [30]. Central Bank of Sri Lanka cancelled the license of Central Investments and Finance PLC (CIFL) and the Standard Credit Finance Limited (TSCFL), two finance companies, in 2018 impacting more than 7000 depositors amounting to Rs. 6.1 billion in value terms [31,32]. The repayments to the depositors under the Sri Lanka Deposit Insurance and liquidity support Scheme has now been initiated by the Central Bank [33]. The Criminal Investigation Department has filed a case at the Magistrate Court of Colombo against the responsible parties for the failure of the CIFL [34].

Having evaluated failure examples from Sri Lankan corporates, the next section analyses causes and mitigating action taken to reduce the failure rates.

\section{Causes and Mitigation Measures to Reduce corporate failure}

There are some common factors that are found in the failure of corporates in Sri Lanka [35]. Excessive exposures, week risk management systems, unethical business practices, mismanagement and continuous accumulated losses have been listed as main factors for the collapse of the companies. These could be overcome through good corporate governance practices, enhancing the regulatory framework, continuous monitoring and reporting of financials to relevant authorities. The article further elaborates steps taken by the CBSL for the close monitoring of financial institutions, increase in the minimum capital requirement and protection measure for the depositor in the form of deposit insurance scheme. There has been instances that government has intervened to protect the depositors. For example, the Deposit insurance scheme was enhanced from Rs. 600,000 to Rs. 1,100,000 to support depositors of six financial companies [36]. These include Central Investments and Finance PLC, The Standard Credit Finance Limited, TKS Finance Limited, The Finance Company PLC, ETI Finance Limited and Swarnamahal Financial Services PLC.

Failure of a single corporate affects related businesses and the total business environment. Business confidence diminishes resulting in diminishing the investor confidence and therefore deviating investors to alternative investment avenues. Furthermore, continuous and regular reporting and monitoring of performance by the regulators is a key factor for early corrective actions to prevent 
corporate failures. One such measure the Government of Sri Lanka has implemented to achieve the above objective is to encourage listing of companies in the Colombo Stock Exchange. Many concessions are given by the 2021 budget speech presented by the Prime Minister of Sri Lanka Hon. Mahinda Rajapaksa for new listing in the Colombo Stock Exchange [37]. A 50\% tax concession for the listing year and to maintain a corporate tax rate of $14 \%$ thereafter for the subsequent three years, providing a tax-deductible expense up to Rs. 100,000 related to investment of listed shares for personal income tax calculation, exemption on taxes on dividends of foreign companies for three years if it's reinvested on expansion of business or in the stock market are some reliefs measure the Government of Sri Lanka has provided to encourage new listing of companies in the Colombo Stock Market [38].

Prevailing low single digit deposit rates encourages new investors to the capital market providing an environment conducive for new listings in the CSE. New Companies listed in the CSE needs to adopt the regulatory and reporting framework of the Colombo Stock Exchange. This would directly include adopting good corporate governance practices, quarterly reporting of performance and disclosure of certain events etc.

\section{CONCLUSION}

The above review examines corporate failures reported during preceding twenty years using published articles. The economic and social impact of failures discussed in detail in the article by providing examples which have been extracted using authentic published sources. Causes leading to corporate failure anlaysed with probable mitigating actions have been proposed to reduce the failure rate.

Though there have been much research carried out during the last 80 years in the failure prediction model building exercise, as elaborated in the above review the phenomena is still common. While only a handful cases are reported and number of enterprise failures are large among small and medium size enterprises and startups. Factors of systematic risk, fraud and political risk should be included in future model building exercise to make the models more robust and useful.

\section{REFERENCES}

1. Beaver, W. (1966). Financial ratios as predictors of failure. Journal of Accounting Research, 5, 71-111.

2. Zavgren, C.V. (1985), "Assessing the vulnerability to failure of American industrial firms: a logistic analysis”, Journal of Business Finance \& Accounting, Vol. 12 No. 1, pp. 19-45.

3. Daubie, M. \& Meskens, Nadine. (2002). Business Failure Prediction: A Review and Analysis of the Literature. 10.1007/978-3-642-57478-8_5. 
4. Doumpos, M., \& Zopounidis, C. (1999). A multinational discrimination method for the prediction of financial distress: the case of Greece, Multinational Finance Journal, 3, 71-101.

5. Bickerdyke I., Lattimore R., Madge A., 2000, Business failure and change: an Australianperspective. Productivity Commission Staff Research Paper, Ausinfo, Canberra, ISBN 174037029 5, p. 1-192

6. Van Caillie D., Arnould S., 2001, The follow-up of financial value creation indicators toprevent bankruptcy in Belgian SMEs: an empirical multivariate approach. Paper presented at the 2001 Babson College Research Conference on Entrepreneurship, Jonköping, Sweden,June 2001.

7. Amrhein D.G., Katz J.A., 1998, Cash flow as a factor in the mortality risk of a business, International Council for Small Business, 1998 Singapore Conference Proceedings, Paper nr.18.A

8. Aziz, M.A. and Dar, H.A. (2006), "Predicting corporate bankruptcy: where we stand?", Corporate Governance, Vol. 6 No. 1, pp. 18-33.

9. Appiah, K.O., Chizema, A. and Arthur, J. (2015), "Predicting corporate failure: a systematic literature review of methodological issues", International Journal of Law and Management, Vol. 57 No. 5, pp. 461-485.

10. Altman, E.I. (1968), Financial ratios, discriminant analysis and the prediction of corporate bankruptcy, Journal of Finance, Vol. 23 No. 4, pp. 589-609.

11. Ohlson, J. (1980). Financial Ratios and the Probabilistic Prediction of Bankruptcy. Journal of Accounting Research, 18(1), 109-131. doi:10.2307/2490395

12. Lennox, C. (1999). Identifying failing companies: a re-evaluation of the logit, probit and DA approaches, Journal of Economics and Business, Volume 51, Issue 4, pp. 347-364.

13. Bell, T. B., Ribar G.S. and Verichio J., 1990, Auditing Symposium X: Proceedings of the 1990 Deloitte \& Touche/University of Kansas Symposium on Auditing Problems, pp. 029-053

14. Khanna, T., (1990), Foundations of Neural Networks, Addison Wesley.

15. Kolodner, J. (1993). Case Base Reasoning ( $1^{\text {st }}$ ed.), Morgan Kaufmann. 
16. Tam, K. Y., \& Kiang, M. Y. (1992). Managerial applications of the neural networks: The case of bank failure predictions. Management Science, 38 (7), 926-947

17. Slowinski, R., and Zopounidis, C., (1994), Rough set sorting of firms according to bankruptcy risk. In Applying Multiple Criteria Aid for Decision to Environmental Management. M.Paruccini, Ed. Kluwer, Dordrecht, Netherlands, 339--357

18. Harvard Business School, Global Impact of the Collapse, Available: https://www.library.hbs.edu/hc/lehman/exhibition/global-impact-of-the-collapse [Jun. 1, 2021].

19. Insurance Journal December 2001, Enron Bankruptcy Has Global Consequences, Available: https://www.insurancejournal.com/news/international/2001/12/03/13297.htm [Jun. 1, 2021].

20. American Bankruptcy Institute December 2020, December 2020 Bankruptcy StatisticsCommercial Filings, Available: https://www.abi.org/newsroom/epiq-stats/december-2020bankruptcy-statistics-commercial-filings [Jun. 3,2021].

21. Sirimane, S. (2011, December 19). Three years after Ceylinco scandal, Daily News, Available : http://archives.dailynews.lk/2011/12/19/bus19.asp [ Jun 3,2021].

22. Daily Mirror February 2016, G-Key Sri Lanka's second largest financial, Available: http://www.dailymirror.lk/105292/G-Key-Sri-Lanka-s-second-largest-financial- ～[ Jun 3, 2021].

23. Abeysinghe, A. (n.d.). Pramuka Savings and Development Bank crisis in Sri Lanka. Retrieved from

https://www.academia.edu/5655062/Pramuka_Savings_and_Development_Bank_Crisis_in_ Sri_Lanka

24. Course hero, Outcome of the collapse of Pramuka Savings and Development bank, available: https://www.coursehero.com/file/56302324/Outcome-of-the-collapse-of-Pramuka-Savingsand-Development-bankdocx/ [Jun. 4, 2021].

25. Daily News August 2020, People's Bank makes compensation payments to ETI, The Finance and Swarnamahal Financial Services depositors, Available : https://www.dailynews.lk/2020/08/05/finance/225097/people\%E2\%80\%99s-bank-makescompensation-payments-eti-finance-and-swarnamahal [ Jun 3,2021]. 
26. Central Bank of Sri Lanka July 2020, Suspension of Business of "ETI Finance Ltd and Swarnamahal Financial Services PLC", Available: https://www.cbsl.gov.lk/sites/default/files/cbslweb_documents/press/pr/press_20200713_sus pension_of_business_of_eti_finance_ltd_and_swarnamahal_financial_services_plc_e.pdf_ [Jun 3,2021].

27. The Morning May 2020, The Finance Company falls a week short of 80, Available: https://www.themorning.lk/the-finance-company-falls-a-week-short-of-80/, [Jun. 4,2021].

28. Colombo Page May 2020, Sri Lanka Central Bank cancels the license of The Finance Company, Available:

http://www.colombopage.com/archive_20A/May22_1590155769CH.php_Jun. 4,2021].

29. Daily News September 2020, Rise and fall of The Finance Company, Available: http://www.dailynews.lk/2020/09/22/finance/229360/rise-and-fall-finance-company, [Jun. $4,2021]$.

30. Lanka News Web April 2019, 13 Sri Lankan finance companies collapse under liquidity issues, Available: https://lankanewsweb.net/business2/41685-13-sri-lankan-financecompanies-collapse-under-liquidity-issues [Jun. 5,2021].

31. Central Bank of Sri Lanka March 2018, Central Investments and Finance PLC Cancellation of Licence issued under the Finance Business Act No. 42 of 2011 and Certificate of Registration issued under the Finance Leasing Act No. 56 of 2000, Available: https://www.cbsl.gov.lk/en/news/cifl-cancellation-of-licence-issued-under-thefinance-business-act-no-42-of-2011-and-certificate-of-registration-issued-under-the-financeleasing-act-no-56-of-2000, [Jun. 5,2021].

32. Central Bank of Sri Lanka June 2018, The Standard Credit Finance Limited - Cancellation of Licence issued under the Finance Business Act No. 42 of 2011 and Certificate of

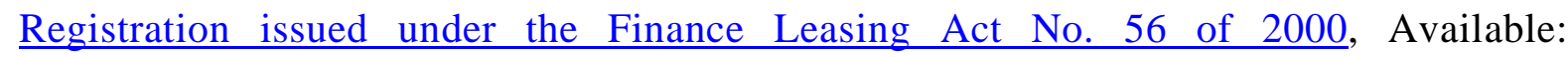
https://www.cbsl.gov.lk/en/news/the-standard-credit-finance-limited-cancellation-of-licenceissued-under-the-finance-business-act-no-42-of-2011-and-certificate-of-registration-issuedunder-the-finance-leasing-act-no-56-of-2000-e, [Jun.5,2021]. 
33. Central Bank of Sri Lanka, Notice to the Depositors of Central investment and Finance PLC, The Standard Credit Finance Limited, TKS Finance Limited, The Finance Company PLC, ETI Finance Limited and Swarnamahal Financial Services PLC, Available:https://www.cbsl.gov.lk/sites/default/files/cbslweb_documents/press/notices/notice _20210402_notice_to_depositors_of_cifl_scfl_tks_tfc_eti_sfs_e.pdf, [Jun. 6,2021].

34. Financial Chronicile December 2013, CIFL depositors continue to file complaints with Fraud Investigation Bureau, Available: https://www.srilankachronicle.com/t31896-cifl-depositorscontinue-to-file-complaints-with-fraud-investigation-bureau [Jun. 7, 2021].

35. Sunday Times March 2021, Central Bank rescues three crisis hit finance companies, Available: http://www.sundaytimes.lk/110327/BusinessTimes/bt35.html [Jun. 7, 2021].

36. Central Bank of Sri Lanka March 2021, Increase of the Maximum Compensation Payment under the Sri Lanka Deposit Insurance and Liquidity Support Scheme (SLDILSS), Available: $\quad$ https://www.cbsl.gov.lk/en/news/increase-of-the-maximum-compensationpayment-sldilss [ Jun. 7,2021].

37. Ministry of Finance, Budget Speech 2021, Available: https://www.treasury.gov.lk/documents/budget/2021/budget_speech_en.pdf, [Jun. 8, 2021].

38. Daily FT November 2020, 2021 Budget support for capital markets; tax concession to promote new listings at CSE, Available: http://www.ft.lk/front-page/2021-Budget-support-for-capitalmarkets-tax-concession-to-promote-new-listings-at-CSE/44-709064 [ Jun. 8,2021]. 